\title{
Dietary intake and the insulin-like growth factor system: effects of migration in two related populations in India and Britain with markedly different dietary intake
}

\author{
AH Heald ${ }^{1, *}$, R Sharma ${ }^{1}$, SG Anderson ${ }^{2}$, A Vyas $^{2}$, K Siddals $^{1}$, J Patel $^{2}$, D Bhatnagar $^{3}$, \\ D Prabharkaran ${ }^{4}$, A Rudenski ${ }^{1}$, E Hughes ${ }^{5}$, P Durrington ${ }^{3}$, JM Gibson ${ }^{1}$ and JK Cruickshank ${ }^{2}$ \\ 'University of Manchester, Salford Royal Hospitals University Trust, Hope Hospital, Stott Lane, Salford, Greater \\ Manchester, M6 8HD, UK: ${ }^{2}$ Clinical Epidemiology Group, University of Manchester Medical School, Manchester \\ M13 9PT, UK: ${ }^{3}$ University Department of Medicine, Manchester Royal Infirmary, Manchester M13 9WL, UK: ${ }^{4} \mathrm{All}$ \\ India Institute of Medical Sciences, New Delhi, India: ${ }^{5}$ Department of Clinical Biochemistry, Sandwell General \\ Hospital, Birmingham, UK
}

Submitted 6 September 2004: Accepted 15 February 2005

\begin{abstract}
Background: The insulin-like growth factor (IGF) system is implicated in the pathogenesis of diabetes and cardiovascular disease.

Objective: We report the effects of total energy intake on the IGF system in two populations with markedly different dietary macronutrient intake and cardiovascular event rate.

Design, subjects and setting: Dietary macronutrient intake was measured in a specific Gujarati migrant community in Sandwell, UK $(n=205)$ compared with people still resident in the same villages of origin in India $(n=246)$. Fasting IGF-I, IGF-binding protein (IGFBP)-1 and IGFBP-3, insulin and glucose (0 and 2-hour) were measured. Results: Total energy and total fat intake were higher in UK migrants, as were IGFBP-3 and IGF-I (mean (95\% confidence interval): 145.9 (138.1-153.6) vs. 100.9 (94.6-107.3) ng ml$\left.{ }^{-1} ; F=76.6, P<0.001\right)$. IGFBP-1 was lower in UK migrants $(29.5(25.9-33.0) \mathrm{vs}$. 56.5 (50.6-62.5) $\left.\mu \mathrm{gl}^{-1} ; F=48.4, P<0.001\right)$. At both sites, IGF-I correlated positively with total energy (Spearman's $\rho=0.45, P<0.001)$ and total fat $(\rho=0.44, P<0.001)$ as did IGFBP-3 with total energy $(\rho=0.21, P<0.05)$ and fat $(\rho=0.26, P<0.001)$. Conversely, in Indian Gujaratis, IGFBP-1 fell with increasing total energy $(\rho=-0.27$, $P<0.001)$ and fat intake $(\rho=-0.26, P<0.01)$ but not in UK Gujaratis. Multiple linear regression modelling showed that increasing quartiles of fat intake were associated with higher IGF-I $(\beta=0.42, P=0.007)$ independent of age, body mass index, plasma insulin, fatty acids and 2-hour glucose.

Conclusion: In these genetically similar groups, migration to the UK and adoption of a different diet is associated with marked changes in the IGF system, suggesting that environmental factors profoundly modulate serum concentrations and actions of IGFs.
\end{abstract}

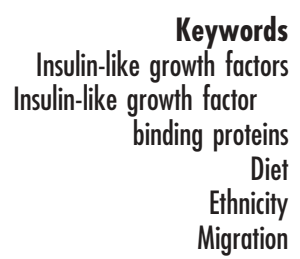

Dietary factors, particularly fat intake, have long been known to affect blood lipid levels ${ }^{1-3}$, but their interactions with novel and potential risk factors are much less clear. An increasing body of evidence has linked the insulin-like growth factor (IGF) system and specifically IGF-I with the pathogenesis of hypertension ${ }^{4}$, atheromatous vascular disease $^{5,6}$, cardiomegaly ${ }^{7}$ and cardiac failure ${ }^{8}$. In cardiomyocytes, IGF-I has an antiapoptotic effect involving pathways dependent on both phosphatidylinositol-3-OH kinase and mitogen-activated protein kinase that lead to expression of the antiapoptotic factor bcl- $2^{9}$. Moreover, polymorphisms associated with low circulating levels of
IGF-I have been linked with an increased risk of type 2 diabetes and myocardial infarction ${ }^{10}$.

At least six high-affinity IGF-binding proteins (IGFBPs) can inhibit or potentiate the actions of IGFs. IGFBP-3 is the principal carrier protein for the IGFs in the circulation ${ }^{11}$. IGFBP-1 is the binding protein thought most relevant to the delivery of IGF-I to metabolically active tissues ${ }^{11}$. We have shown that the relationship of low circulating IGF-I with subsequent glucose intolerance is considerably amplified in the presence of low circulating IGFBP- $1^{12}$ and that lower serum IGFBP-1 concentrations are linked with insulin resistance, impaired glucose tolerance and cardiovascular 
risk $^{13}$. In a Danish nested case-control study, individuals without ischaemic heart disease (IHD) at baseline but with low circulating IGF-I levels and high IGFBP-3 levels had a significantly increased risk of developing IHD during a 15-year follow-up period ${ }^{14}$. A recent Rancho-Bernardo study report ${ }^{15}$ examined the prospective association of serum IGF-I and IGFBP-1 with all-cause mortality, IHD and non-IHD cerebrovascular disease (CVD) mortality in older adults (51-98 years old). They found that low baseline levels of IGF-I and IGFBP-1 increased the risk of fatal IHD among elderly men and women independent of prevalent IHD and CVD risk factors.

In a cross-sectional study, we found that the IGF system differed by European versus African-Caribbean versus Pakistani ethnicity ${ }^{13}$ and that there were significant modulating effects of dietary carbohydrate, fat and protein intakes on IGF levels ${ }^{16}$. These relationships differed across the three ethnic groups studied according to dietary macronutrient intake. Thus dietary factors, the IGF system and how these are shared by or differ with ethnic group all appear to contribute to the development of diabetes and macrovascular disease.

Recently, Harding found that cardiovascular and cancer mortality of South Asian migrants increased with duration of residence in England and Wales ${ }^{17}$. Our hypothesis in the present work was that the lifestyle changes that occur with population migration for a particular ethnic group are mirrored by specific changes in the IGF system, and that these changes would be related to alterations in macronutrient intake.

\section{Methods}

\section{Study sample}

The study was a direct population comparison between Gujarati 'Patels' living in Navsari, Gujarat, India and people from the same community who migrated to Sandwell, England. In Sandwell, 343 Gujarati 'Patels' were randomly selected using the 1998 electoral register, a local community directory from the local temple and general practitioner primary care. Of these, 205 participants completed the study with full blood samples. The majority of these people had been in Britain for more than two decades, with only eight for less then 10 years. Country of birth varied from India, East and South Africa to a small number of younger people born in Britain. Inclusion criteria were age over 25 years, not being pregnant and no prior diagnosis of diabetes, cardiovascular disease or malignant tumour. A mutually convenient appointment was made for the individual at either a local surgery or the local hospital.

In India, the team visited five villages surrounding Navsari, where 'Patels' were the majority. Community elders and residents were given information about the study and an invitation to a group meeting to discuss the study. The 1999 electoral register was supplemented with fuel ration card registers. Letters were given or sent to 300 people using the same criteria as in Britain and appointments made. Of these, 246 subjects completed the study and gave blood at a central clinic.

Following an overnight fast, a fasting capillary blood sample was taken from each subject and a $75 \mathrm{~g}$ oral glucose tolerance test (OGTT) started. During this, they completed a demographic and medical questionnaire. Anthropometric data were collected by carefully standardised methods.

Ethical approval for the study was obtained from the Sandwell Local Research Ethics Committee (West Midlands, UK) and from the National Research Ethics Body in New Delhi, India.

\section{Dietary method}

On this visit participants were also given a 4-day food diary to complete. The diaries were collected and checked in situ by local staff or nutritionists, again carefully trained by the same senior nutritionist (A.V.) who organised the nutritional assessment at both sites. Food diaries were collected over four consecutive days to include at least one weekend day. Portion sizes were recorded as household measures. Nutritionists or trained fieldworkers collected weights of average portions to calibrate the household measures in both sites. Size and weight of home-made breads and other specific foods were recorded. Three to five recipes were collected for all composite dishes used in both sites. Dietitians or nutritionists did all data entry. Diaries were analysed using the WISP ${ }^{\circledR}$ (Weighed Intake Software Program) nutritional package (version 1.23; Tinuviel Software, Llanfechell, UK; http://www.tinuviel. u-net.com/wisp.htm).

\section{Measurement of physical activity}

A Caltrac monitor (Muscle Dynamics, Torrance, CA, USA) was used to measure physical activity, and has been validated several times ${ }^{18}$. Individuals were asked to wear it continuously on the chest, to be removed only when sleeping or bathing, then to have the Caltrac reading taken after $48 \mathrm{~h}$. They completed the food diary at the same time.

\section{Collection and transport of blood samples}

All samples were taken between 9.00 and 10.00 a.m. at Sandwell, between 8.30 and 9.30 a.m. at Navsari, the patient having fasted from 11 p.m. on the previous evening. The data collection period was April 1998 to May 2001 or October 1998 to June 2001 in Sandwell and Navsari, respectively. In Sandwell the subjects attended for OGTT at the local hospital, a central health centre or a general practice in the north of the town. In India, all subjects were collected from the villages around the city early in the morning and driven to the study base, on the outskirts of the city of Navsari.

At both sites, blood for glucose determination was collected into fluoride oxalate (Sarsted tubes) and stored at 
$4^{\circ} \mathrm{C}$ until the end of the clinic session (between 12.00 midday and 1.00 p.m.), when samples were transported on ice to the local laboratory for analysis. Collection of blood for determination of IGF-I, IGFBP-1, IGFBP-3, nonesterified fatty acids (NEFA) and insulin was into lithium heparin tubes. All samples were spun, separated, and the plasma stored in liquid nitrogen and transported to Delhi every 4 months. Samples were transported from India to the UK by air, using dry ice (Dry shippers; BDH-Merck, UK). Subsequent storage was at $-70^{\circ} \mathrm{C}$.

\section{Laboratory methods}

The samples from India and the UK were randomised in the same batches for all assays.

IGFBP-1 levels were determined by an in-house antibody-based assay ${ }^{19}$ with a detection limit of $3 \mu \mathrm{gl}^{-1}$ and within- and between-assay coefficients of variation (CVs) of $<8 \%$. IGF-I was measured using the DPC (Los Angeles, CA, USA) Immulite autoanalyser. IGFBP-3 was measured using the DSL (Webster, TX, USA) immunoradiometric assay. Within- and between-assay CVs for IGF-I and IGFBP-3 were less than 5\%.

Plasma glucose was determined in the Department of Biochemistry, Sandwell Hospital and the Mankodi Laboratory, Navsari. Both sites used glucose oxidase autoanalyser methods, the Vitros ${ }^{\circledR} 950$ (Vitros, Rochester, NY, USA) in Britain and Technicon RA- $50^{\mathrm{TM}}$ (Bayer Diagnostics, Baroda, India) in Gujarat, and sample comparison. Cross-site CV was $<5 \%$ across the range of glucose values.

Fasting NEFA concentration was measured using the WAKO (Neuss, Germany) enzyme-linked immunosorbent assay (ELISA) for total NEFA. This is a standard ELISA that relies on the acylation of coenzyme A by the fatty acids to produce hydrogen peroxide. In the presence of a purple dye, the amount of hydrogen peroxide generated is measured colorimetrically. Assay sensitivity was $0.05 \mathrm{mmol}^{-1}$ and inter- and intra-assay CVs $<10 \%$.

Serum insulin was measured by a modified in-house assay, using charcoal extraction ${ }^{20}$ with $30 \%$ cross-reactivity for pro-insulin. HOMA-S (insulin sensitivity) and HOMA-B (pancreatic $\beta$-cell function) were calculated from fasting insulin and glucose concentrations, using an iterative computer program utilising a non-linear model for glucose and insulin homeostasis ${ }^{21,22}$.

\section{Statistical methods}

Data were analysed using the statistical package Intercooled Stata version 8.0 (Stata Corp., College Station, TX, USA). Anthropometric and metabolic data are expressed as arithmetic means with 95\% confidence intervals (CI). Comparison of means was by $t$-test or analysis of variance. Logarithmic transformation was performed on nonnormally distributed variables. For univariate correlation between continuous variables, the Spearman correlation coefficient $(\rho)$ was used. In both univariate and multivariate regression analyses, the normalised $\beta$ coefficients presented allow direct comparison (along a scale of $0-1$ ) of the strength of each association. As not all subjects had all measurements owing to missing samples, numbers varied between analyses.

\section{Results}

\section{Demographic factors}

Men and women at both locations had similar age distributions (Table 1). Alcohol drinking was higher in Sandwell men than in Navsari men, with hardly any Navsari Gujarati women being alcohol consumers. Body mass index (BMI) and waist-to-hip ratio were significantly greater in Sandwell.

\section{Dietary data}

Total energy intake was higher in UK migrants (mean (95\% CI): $2221(2054-2386) \mathrm{kcalday}^{-1}$ for men, 1720 (1595-1847) $\mathrm{kcal} \mathrm{day}^{-1}$ for women) than in India (1478 (1347-1610) $\mathrm{kcalday}^{-1}$ for men, 1260 (1174-1348) $\mathrm{kcalday}^{-1}$ for women). Similarly, total fat intake was higher in UK migrants (man and women) as were total protein intake and carbohydrate intake (Table 2).

Table 1 Lifestyle factors among Gujarati Indians in Sandwell (UK) compared with contemporaries living in Navsari (India)

\begin{tabular}{|c|c|c|c|c|}
\hline \multirow[b]{2}{*}{ Lifestyle factor } & \multicolumn{2}{|c|}{ Men } & \multicolumn{2}{|c|}{ Women } \\
\hline & $\begin{array}{l}\text { Navsari } \\
(n=139)\end{array}$ & $\begin{array}{l}\text { Sandwell } \\
(n=119)\end{array}$ & $\begin{array}{l}\text { Navsari } \\
(n=155)\end{array}$ & $\begin{array}{l}\text { Sandwell } \\
(n=123)\end{array}$ \\
\hline Age (years) & $49.1(46.8-51.5)$ & $49.0(46.8-51.3)$ & $48.5(46.3-51.3)$ & $49.2(47.1-51.3)$ \\
\hline$\%$ Further education & $7.4(3.1-11.8)$ & $51.4(43.5-59.3)^{*}$ & $20.1(12.8-27.5)$ & $28.6(20.5-36.8)$ \\
\hline$\%$ Smokers (current) & $39.7(31.6-47.8)$ & $10.2(4.5-15.0)^{\star \star}$ & $3.2(0-6.4)$ & 0 \\
\hline$\%$ Alcohol drinkers & $60.0(51.9-68.2)$ & $75.8(69.1-82.6)^{*}$ & $0.7(0-2.2)$ & $29.6(21.4-37.8)^{*}$ \\
\hline Height $(\mathrm{m})$ & $1.64(1.63-1.65)$ & $1.67(1.67-1.68)^{*}$ & $1.52(1.51-1.53)$ & $1.53(1.52-1.54)$ \\
\hline Body mass index $\left(\mathrm{kg} \mathrm{m}^{-2}\right)$ & $21.0(20.3-21.7)$ & $25.9(25.1-26.7)^{\star *}$ & $20.8(20.3-21.6)$ & $26.6(25.7-27.3)^{\star *}$ \\
\hline Waist-to-hip ratio & $0.87(0.86-0.88)$ & $0.92(0.90-0.94)^{* *}$ & $0.79(0.78-0.80)$ & $0.82(0.80-0.84)^{*}$ \\
\hline
\end{tabular}

Values are \% or mean (95\% confidence interval).

${ }^{*} P<0.05,{ }^{* *} P<0.001$ : Navsari vs. Sandwell.

†Those who achieved a level of literacy beyond secondary school (or equivalent). 
Table 2 Nutritional data among Gujarati Indians in Sandwell (UK) compared with contemporaries living in Navsari (India)

\begin{tabular}{|c|c|c|c|c|}
\hline & \multicolumn{2}{|c|}{ Men } & \multicolumn{2}{|c|}{ Women } \\
\hline & Navsari & Sandwell & Navsari & Sandwell \\
\hline Energy intake $\left(\mathrm{kcal} \mathrm{day}^{-1}\right)$ & $1478(1347-1610)$ & $2221(2054-2386)^{\star \star}$ & $1260(1174-1348)$ & $1720(1595-1847)$ \\
\hline $\begin{array}{l}\text { Measured physical activity as } \\
\text { 'energy expenditure' (kcal day }{ }^{-1} \text { ) }\end{array}$ & $1890(1744-2037)$ & $2246(2112-2381)^{*}$ & $1637(1553-1721)$ & $1782(1640-1924)$ \\
\hline Total fat intake $\left(\mathrm{g} \mathrm{day}^{-1}\right)$ & $55.1(47.2-63.1)$ & $97.2(89.7-104.8)^{\star \star}$ & $45.9(41.1-50.8)$ & $74.3(70.2-78.5)^{\star *}$ \\
\hline Saturated fat intake $\left(\mathrm{g} \mathrm{day}^{-1}\right)$ & $12.4(9.7-15.2)$ & $25.4(22.9-27.8)^{\star \star}$ & $11.0(8.8-13.2)$ & $19.1(17.6-20.6)^{* *}$ \\
\hline Total protein intake $\left(\mathrm{g} \mathrm{day}^{-1}\right)$ & $52.1(43.9-60.4)$ & $78.7(73.7-83.7)^{\star \star}$ & $38.4(34.9-41.8)$ & $54.7(51.5-58.0)^{\star \star}$ \\
\hline Carbohydrate intake (g day ${ }^{-1}$ ) & $177.5(164.0-190.9)$ & $268.4(252.7-284.1)^{\star \star}$ & $164.7(154.7-174.7)$ & $226.5(212.9-240.1)^{\star \star}$ \\
\hline$\%$ Energy from fat & $32.6(30.4-34.8)$ & $38.46(37.1-39.9)^{\star \star}$ & $32.9(31.3-34.7)$ & $39.43(38.5-40.4)^{\star \star}$ \\
\hline$\%$ Energy from carbohydrate & $54.08(51.5-56.6)$ & $43.5(41.7-45.3)^{\star *}$ & $54.8(52.9-56.7)$ & $48.5(47.4-49.4)^{\star \star}$ \\
\hline
\end{tabular}

Values are $\%$ or mean (95\% confidence interval).

${ }^{\star} P<0.05,{ }^{\star \star} P<0.001$ : Navsari vs. Sandwell.

\section{IGF-I and dietary macronutrient intake}

IGF-I was markedly higher in migrant Gujarati men and women than in Indian Gujarati men and women (mean (95\% CI): 145.9 (138.1-153.6) vs. 100.9 (94.6-107.3) $\left.\mathrm{ng} \mathrm{ml}^{-1} ; F=76.6, P<0.001\right)$ and correlated positively with total energy intake (Spearman's $\rho=0.45, P<0.001$ ). The positive relationship of IGF-I with total energy intake was similar in Navsari (Fig. 1a). IGF-I correlated positively with total fat intake $(\rho=0.44, P<0.001)$ but the relationship was stronger in Navsari (Fig. 2a), $P$ for difference between the gradients $=0.02$. There was a trend for IGF-I to increase by total protein intake at both sites (Fig. 3a). Carbohydrate intake was not associated with any changes in circulating IGF-I in univariate analysis but see below for multivariate results.

\section{IGFBP-1 and dietary macronutrient intake}

IGFBP-1 was lower in UK migrants (mean (95\% CI): 29.5 (25.9-33.0) vs. $56.5(50.6-62.5) \mu g^{-1} ; \quad F=48.4$, $P<0.001)$. IGFBP-1 correlated negatively with total energy in Navsari $(\rho=-0.27, P<0.001)$ but not in Sandwell (Fig. 1b), $P$ for difference between gradients $<0.001$. A lower IGFBP-1 was associated with increasing total fat intake only in Navsari $(\rho=-0.26, P<0.01)$ (Fig. 2b), $P$ for difference between gradients $<0.001$. IGFBP-1 fell with elevated protein intake at both sites (Fig. 3b). Carbohydrate intake was not associated with any changes in circulating IGFBP-1 in univariate analysis.

\section{IGFBP-3 and dietary macronutrient intake}

IGFBP-3 was markedly higher in UK migrant Gujarati men (mean (95\% CI): $3.9(3.7-4.1) \mathrm{mgl}^{-1}$ ) and women (3.9 $\left.(3.7-4.1) \mathrm{mg} \mathrm{l}^{-1}\right)$ than in Indian Gujarati men and women (both $3.5(3.3-3.7) \mathrm{mgl}^{-1} ; F=6.4, P<0.001$ ). IGFBP-3 was positively associated with total energy $(\rho=0.21$, $P<0.05$ ) at both sites (Fig. 1c) and total fat intake $(\rho=0.26, P<0.001)$ at both sites, so that IGFBP-3 in Navsari $=3.28+0.58 \times$ fat $\left(\mathrm{g} \mathrm{day}^{-1} / 100\right)$, and in Sandwell, $2.42+0.52 \times$ fat $\left(\mathrm{g} \mathrm{day}^{-1} / 100\right)$.
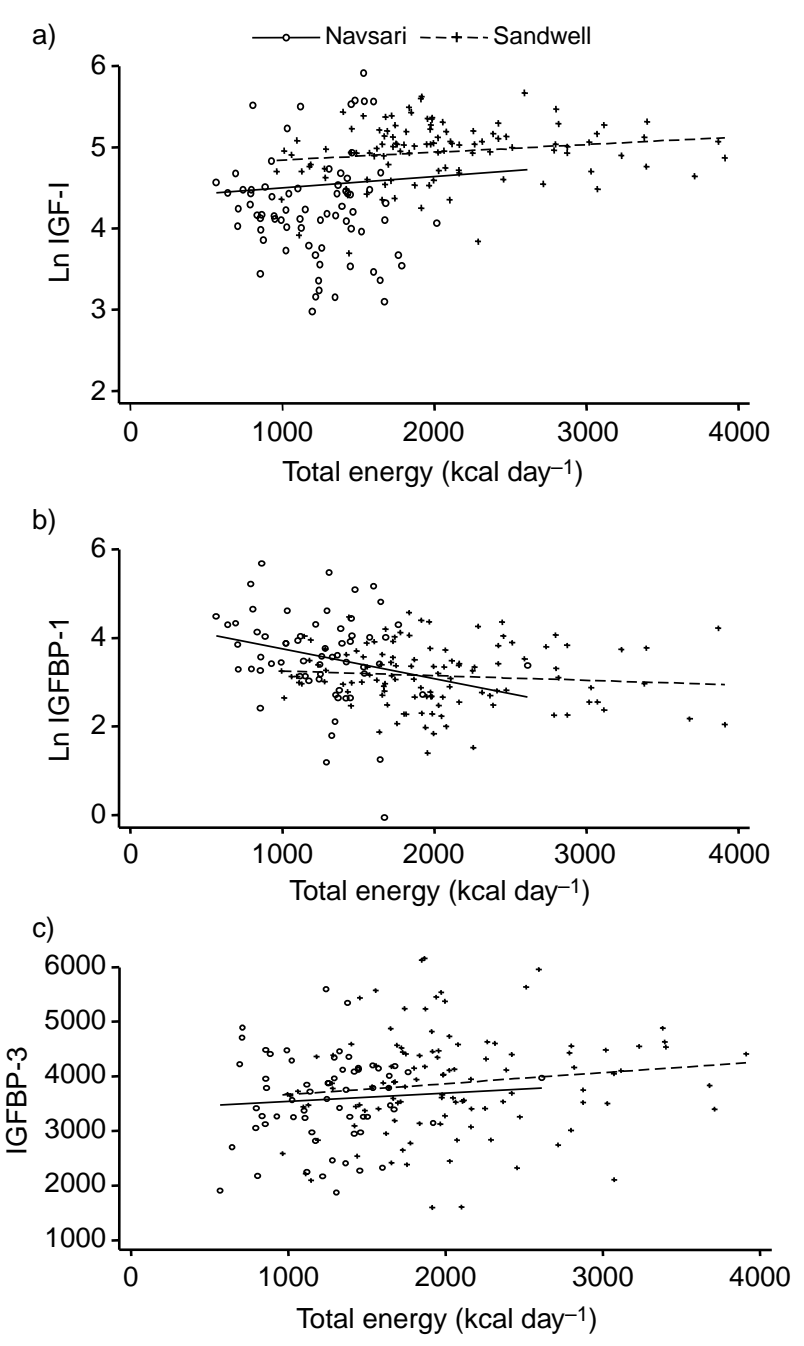

Fig. 1 Relation between insulin-like growth factor (IGF)-I, IGFbinding protein (IGFBP)-1 and IGFBP-3 and total energy intake. (a) LnIGF-I vs. total energy intake: InIGF-I $=4.36+0.14 \times$ energy $\left(\mathrm{kcal} \mathrm{day}^{-1}\right.$ ) in Navsari; In IGF-I $=4.75+0.09 \times$ energy (Mcal day $^{-1}$ ) in Sandwell. (b) Ln IGFBP-1 vs. total energy intake: In IGFBP-1 $=4.42-0.6 \times$ energy $\quad\left(\right.$ Mcal day $\left.^{-1}\right)$ in Navsari; In IGFBP-1 = $3.35-0.1 \times$ energy $\left(\right.$ Mcal day $^{-1}$ ) in Sandwell. (c) IGFBP-3 vs. total energy intake: IGFBP-3 $=3.46+0.2 \times$ energy $\left(\right.$ Mcal day $^{-1}$ ) in Navsari; IGFBP-3 $=3.39+0.15 \times$ energy $\left(\right.$ Mcal day $\left.^{-1}\right)$ in Sandwell 
624
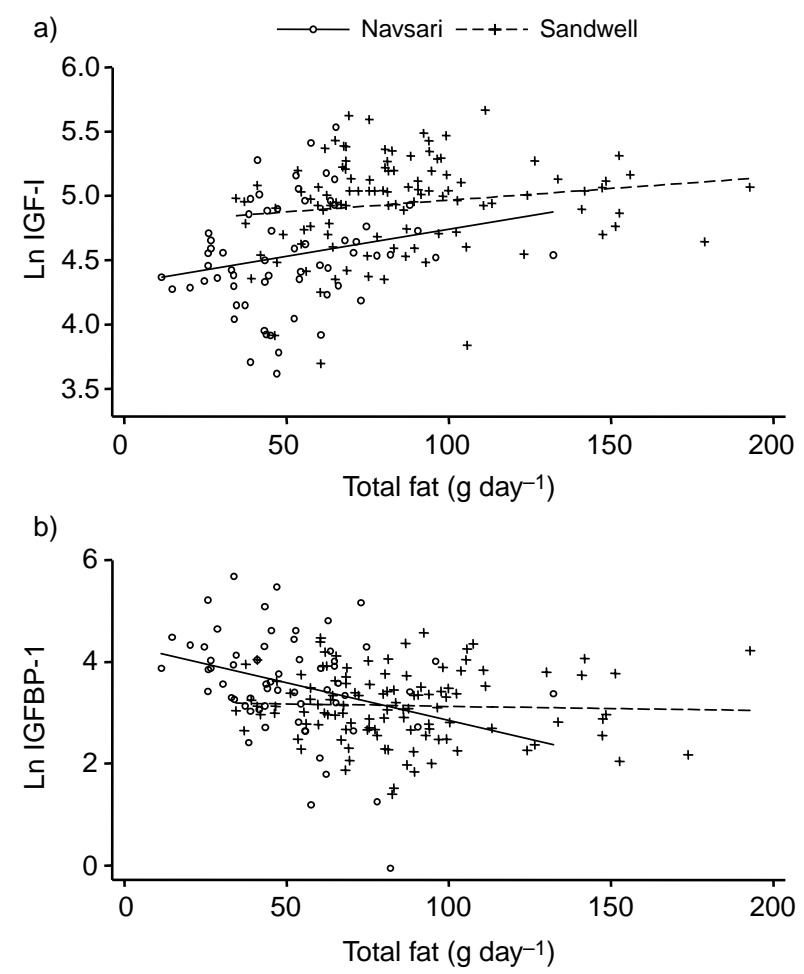

Fig. 2 Relation between insulin-like growth factor (IGF)-I and IGF-binding protein (IGFBP)-1 and total fat intake. (a) Ln IGF-I vs. total fat intake: In IGF-I $=4.32+0.4 \times$ fat $\left(\mathrm{g} \mathrm{day}^{-1} / 100\right)$ in Navsari; In IGF-I $=4.78+0.18 \times$ fat $\left(\mathrm{g} \mathrm{day}^{-1} / 100\right)$ in Sandwell. (b) Ln IGFBP-1 vs. total fat intake: In IGFBP-1 $=4.33-1.47 \times$ fat $\left(\right.$ g day $\left.^{-1} / 100\right)$ in Navsari; In IGFBP-1 $=3.22-0.09 \times$ fat (g day ${ }^{-1 / 100)}$ in Sandwell

\section{IGF-I and IGFBP-1 and energy expenditure}

For Navsari Gujaratis, increasing energy expenditure was strongly associated with higher IGF-I (normalised $\beta$ for univariate regression $=0.25, P<0.001$ ), but not in Sandwell (Fig. 4a), $P$ for difference in gradients $=0.002$.

At both sites, increasing energy expenditure was significantly associated with lower IGFBP-1: $\beta=-0.20$, $P=0.002$ for Navsari and $\beta=-0.31, P=0.009$ for Sandwell (Fig. 4b), $P$ not significant for difference between gradients.

\section{Multiple linear regression analysis}

\section{$I G F-I$}

Multivariate regression analysis in a model that also included BMI, fasting insulin, fasting NEFA and 2-hour glucose showed that higher ln IGF-I was associated independently with increasing quartile of fat intake (highest vs. lowest quartile: $\beta=0.42, P=0.007$ ), decreasing quartile of carbohydrate intake (first vs. second quartile: $\beta=-0.17, P=0.005)$, decreasing quartile of protein intake (highest vs. lowest quartile: $\beta=-0.27$, $P=0.06)$ and male gender $(\beta=0.21, P=0.009)$ and negatively with age $(\beta=-0.36, P<0.001)$.
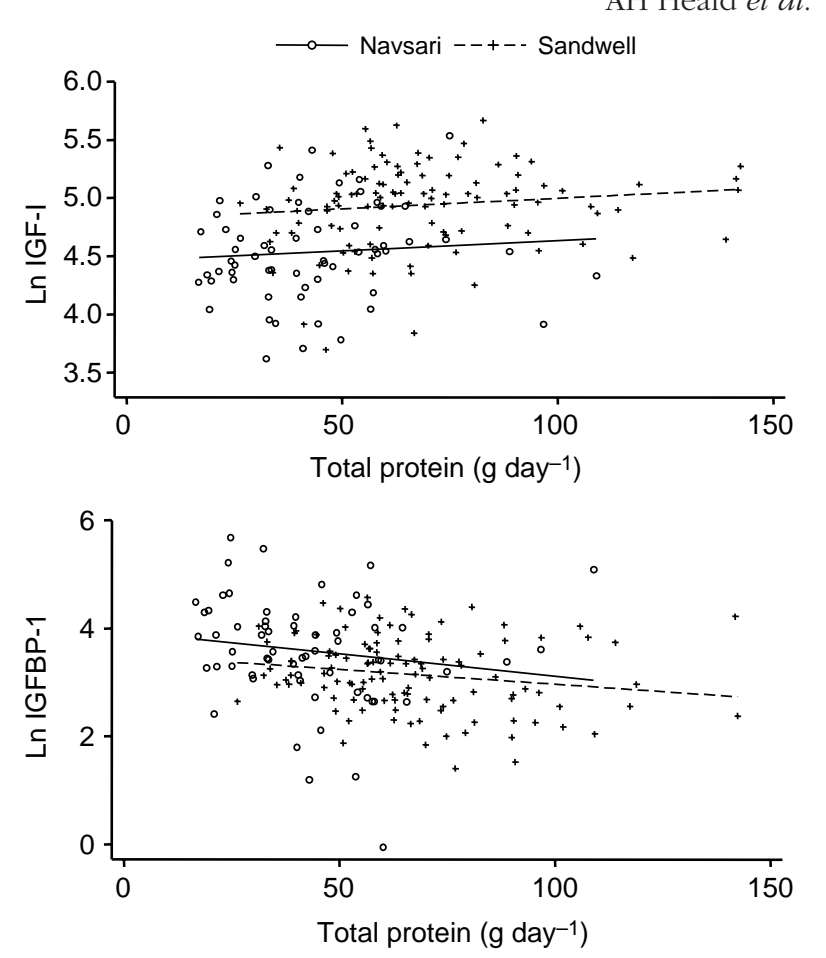

Fig. 3 Relation between insulin-like growth factor (IGF)-I and IGF-binding protein (IGFBP)-1 and total protein intake. (a) Ln IGFI vs. total protein intake: InIGF-I $=4.38+0.17 \times$ protein

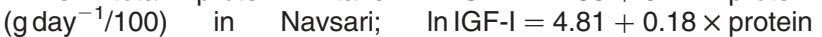
( day $^{-1 / 100)}$ in Sandwell. (b) Ln IGFBP-1 vs. total protein intake: In IGFBP-1 $=3.93-0.82 \times$ protein $\left(\right.$ g day $\left.^{-1} / 100\right)$ in Navsari; In IGFBP-1 $=3.51-0.55 \times$ protein $\left(\mathrm{g} \mathrm{day}^{-1 / 100}\right)$ in Sandwell

\section{IGFBP-1}

Multivariate regression analysis in a model that also included gender, fasting NEFA, 2-hour glucose, quartiles of fat and quartiles of carbohydrate showed that ln IGFBP-I was independently negatively associated with increasing quartile of protein intake (highest vs. lowest quartile: $\beta=-0.26, P=0.04)$, BMI $(\beta=-0.50, P<0.001)$ and fasting insulin $(\beta=-0.15, P=0.05)$ and positively associated with age $(\beta=0.17, P=0.01)$

\section{IGFBP-3}

Multivariate regression analysis in a model that also included gender, BMI, fasting NEFA, fasting insulin, 2-hour glucose, quartiles of dietary protein and quartiles of dietary carbohydrate showed that IGFBP-3 was independently negatively associated with age $(\beta=-0.28$, $P=0.02$ ) and positively associated with increasing quartile of fat intake (third vs. first quartile: $\beta=0.36$, $P=0.03$; fourth vs. first quartile: $\beta=0.42, P=0.04$ ).

\section{Discussion}

In two Gujarati populations of similar genetic origin, there were significant differences in levels of circulating IGF-I, IGFBP-3 and IGFBP-1 depending on whether people had 


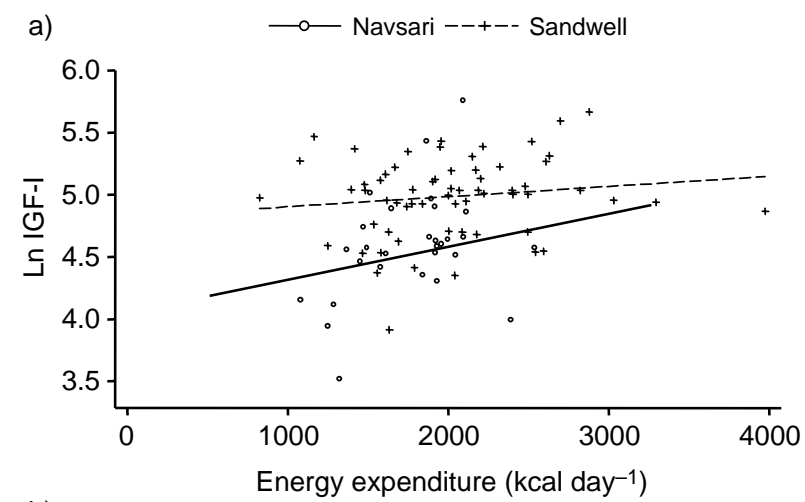

concentration for IGF-I as nutritional restriction is for reducing the concentration of this peptide ${ }^{23}$. The other contributing factor may be that limited food availability increases the absorptive power of the gut ${ }^{27}$. This is certainly true for micronutrients such as iron, as specific transporters are upregulated in human deficiency states ${ }^{28}$. Direct evidence is lacking for increased macronutrient transporter expression in the food-restricted human gut, but it clearly occurs in mouse, rat and chicken models of chronic privation $^{29}$. The evidence is strongest for increased glucose transport, including upregulation of SGLT-1 (sodium-dependent glucose transporter-1) expression. In addition, the intestinal hypertrophy consequent upon small bowel resection confirms that the gut is innately adaptive in attempting to maintain nutritional requirements ${ }^{30}$.

Thus absorption of macronutrients may have been more effective in Navsari with a consequent greater upregulation of IGF-I for any given change in total energy intake. In univariate analysis a similar positive trend for IGF-I was seen with increase in protein intake, as found in older studies suggesting higher protein intake increases IGF-I levels $^{23}$. However, in multivariate analysis the association of IGF-I with total protein was in the opposite direction and of marginal significance. The data illustrate the importance of attempting to control for potential confounders in these complex diet-metabolic relationships. There was a wide spread and similar scatter in protein intake across the two groups, most likely because the source of protein in both groups was mainly lentils and pulses (data not shown).

IGFBP-1 was negatively related to total energy intake in migrated to the UK or remained in Gujarat, India. The marked difference between the two groups suggests that environmental exposure, particularly quality and types of macronutrient intake, and lifestyle factors, profoundly influence the IGF system.

It is well established that an increased total energy intake results in higher levels of $\mathrm{IGF}^{23}$. The higher circulating IGF-I and IGFBP-3 in Sandwell was related to increased synthesis of IGF-I and IGFBP-3 in relation to this group's greater total energy intake. Starvation and fasting cause low serum IGF-I levels ${ }^{24}$. An increase in IGF-I consistently follows improved energy intake ${ }^{25}$. Thus the changes that we see in circulating IGF-I and IGFBP-3 with migration to the UK are consistent with previous dietary intervention studies.

IGF-I also showed a direct relationship to total fat intake in both groups. This is in accordance with the study of Kaklamani et al., where comparison was made of the effect of dietary fat and carbohydrates on IGF-I ${ }^{26}$. The relationship of IGF-I with fat intake was stronger in Navsari than in Sandwell, where IGF-I was already higher. Thus there may be a 'ceiling effect' of fat intake on IGF-I synthesis. In relation to this, it has been shown that nutrient surfeit is not as potent a stimulus for raising the Navsari. This group also showed a reduction in IGFBP-1 with increasing fat consumption, whereas in Sandwell there was no change in IGFBP-I in relation to increased total energy and fat consumption. It seems that IGFBP-1 was already suppressed in Sandwell Gujaratis and therefore a further change in diet made no or very little difference to circulating IGFBP-1. Portal blood insulin is thought to be amongst the most potent regulators of IGFBP-1 secretion from the liver ${ }^{31}$ but it may be that macronutrient intake is earlier in this pathway, as shown by the multivariate model here and insulin's marginal relationship in it. The relationship of IGFBP-1 with protein intake was negative in both groups as seen previously ${ }^{16}$.

Insulin resistance was greater in migrant Sandwell men than their Navsari counterparts (data not shown). $\beta$ Pancreatic cell secretory capacity (HOMA-B) was similarly raised in this group. This may well be a compensatory phenomenon to manage higher energy intake, putting more demand on the pancreatic $\beta$ cells in the context of reduced insulin sensitivity. Intriguingly, differences in C-peptide or insulin concentration were found a decade ago to virtually account for ethnic differences of increased rates of diabetes now so prominent in these communities ${ }^{32}$. It was suggested 
then that a nutritional rather than a metabolic cause underlay these ethnic differences, as shown here in relation to the IGF system ${ }^{33}$.

Apart from dietary changes, physical activity levels differed between the migrant and non-migrant communities. UK migrant men were more physically active with no significant difference for females (Table 2). IGF-I increased with increasing energy expenditure in Navsari Gujaratis, as found in one earlier study ${ }^{33}$, but here was only found in India. There was a reduction in IGFBP-I with increasing energy expenditure in both sites. Previous intervention studies have shown differing effects of exercise on IGFBP- $1^{34-36}$. Most of these studies were very small, but an inverse relation as found here is possible, because hepatic insulin sensitivity also improves with exercise, leading to decreased IGFBP-1 production in relation to any given hepatic portal insulin level.

Abnormalities in the IGF system can predispose individuals to cancer, cardiovascular disease and type 2 diabetes mellitus ${ }^{10}$. Experiments on animals have shown that energy restriction can reduce the risk of cancer and inhibit tumour growth ${ }^{37,38}$ and this effect can be attributed in part to modulation of IGF action ${ }^{39,40}$. Restriction of energy intake in rats transplanted with human prostate cancer cells slows the growth of the cancer and accelerates apoptosis $^{39}$. These effects are associated with a decrease in circulating IGF-I. Furthermore, the beneficial effects of dietary restriction on reducing the growth rate of bladder cancer in mice are abrogated upon administration of IGF$\mathrm{I}^{40}$. This suggests that the effect of energy restriction on cancer may be mediated mainly through IGF-I. We hypothesise that such differences in IGF-I bioavailability account for some of the differences in disease prevalence between non-migrants and individuals who moved from Gujarat to the UK.

The phenotype of circulating IGF/IGFBP concentration is the result of a complex interaction between various, often competing, stimuli. The balance of these stimuli in relation to IGF action is therefore likely to be critical. Thus, for benefit on cardiovascular outcomes, higher circulating IGF-I seems appropriate while its excess appears to be related to various cancers. Although our study has demonstrated an association of total energy and dietary factors with the IGF system, the exact nature of the doseresponse relationships between macronutrients and levels of IGFs in the circulation remains to be determined and is limited by the imprecision of the dietary measures currently available. The data here provide important evidence for the effect of environmental factors in modulating the concentration and biological effects of IGFs in a genetically similar population. Further experimental studies should help to evaluate the exact nature of the relationship between the macronutrients and the IGF system and to ascertain how dietary intervention might modify an individual's risk of cancer and cardiovascular disease in later life.

\section{Acknowledgements}

We acknowledge the support of the British Heart Foundation in funding this study. No author has any conflict of interest.

\section{References}

1 Keys A. Coronary heart disease - the global picture. Atherosclerosis 1975; 22: 149-92.

2 Grande F, Anderson JT, Keys A. Comparison of effects of palmitic and stearic acids in the diet on serum cholesterol in man. American Journal of Clinical Nutrition 1970; 23: 1184-93.

3 Sirtori CR, Tremoli E, Gatti E, Montanari G, Sirtori M, Colli S, et al. Controlled evaluation of fat intake in the Mediterranean diet: comparative activities of olive oil and corn oil on plasma lipids and platelets in high-risk patients. American Journal of Clinical Nutrition 1986; 44: 635-42.

4 Fath KA, Alexander RW, Delafontaine P. Abdominal coarctation increases insulin-like growth factor I mRNA levels in rat aorta. Circulation Research 1993; 72: 271-7.

5 Ververis JJ, Ku L, Delafontaine P. Regulation of insulin-like growth factor I receptors on vascular smooth muscle cells by growth factors and phorbol esters. Circulation Research 1993; 72: $1285-92$.

6 Delafontaine P. Insulin-like growth factor I and its binding proteins in the cardiovascular system. Cardiovascular Research 1995; 30: 825-34.

7 Duerr RL, Huang S, Miraliakbar HR, Clark R, Chien KR, Ross J Jr. Insulin-like growth factor-I enhances ventricular hypertrophy and function during the onset of experimental heart failure. Journal of Clinical Investigation 1995; 95: 619-27.

$8 \mathrm{Li} \mathrm{Q}, \mathrm{Li} \mathrm{B}$, Wang X, Leri A, Jana KP, Liu Y, et al. Overexpression of insulin-like growth factor-I in mice protects from myocyte death after infarction, attenuating ventricular wall dilatation, wall stress and cardiac hypertrophy. Journal of Clinical Investigation 1997; 100: 1991-9.

9 Mehrhof FB, Müller FU, Bergmann MW, Li P, Yibin Wang Y, Schmitz W, et al. In cardiomyocyte hypoxia, insulin-like growth factor-I-induced antiapoptotic signaling requires phosphatidylinositol-3-OH-kinase-dependent and mitogenactivated protein kinase-dependent activation of the transcription factor cAMP response element-binding protein. Circulation 2001; 104: 2088-94.

10 Vaessen N, Heutink P, Janssen JA, Witteman JC, Testers L, Hofman A, et al. A polymorphism in the gene for IGF-I: functional properties and risk for type 2 diabetes and myocardial infarction. Diabetes 2001; 50: 637-42.

11 Juul A. Serum levels of insulin-like growth factor-I and its binding proteins in health and disease. Growth Hormone and IGF Research 2003; 13: 113-70.

12 Sandhu MS, Heald AH, Gibson JM, Cruickshank JK, Dunger $\mathrm{DB}$, Wareham NJ. Circulating concentrations of insulin-like growth factor-I and the development of glucose intolerance: a prospective observational study. Lancet 2002; 359: $1740-5$.

13 Cruickshank JK, Heald AH, Anderson SG, Cade JE, Sampayo J, Riste LK, et al. The epidemiology of the insulin-like growth factor system in 3 ethnic groups. American Journal of Epidemiology 2001; 154: 504-13.

14 Juul A, Scheike T, Davidsen M, Gyllenborg J, Jørgensen T. Low serum insulin-like growth factor-I is associated with increased risk of ischaemic heart disease: a populationbased case-control study. Circulation 2002; 106: 939-44.

15 Laughlin GA, Barrett-Connor E, Criqui MH, Kirtz-Silverstein D. The prospective association of insulin like growth factor-I and IGF-binding protein-1 levels with all cause and 
cardiovascular disease mortality in older adults: The RanchoBernardo study. Journal of Clinical Endocrinology and Metabolism 2004; 89: 114-20.

16 Heald AH, Cade JE, Cruickshank JK, Anderson S, White A, Gibson JM. The influence of dietary intake on the insulin-like growth factor (IGF) system across three ethnic groups: a population-based study. Public Health Nutrition 2003; 6: $175-80$.

17 Harding S. Mortality of migrants from the Indian subcontinent to England and Wales: effect of duration of residence. Epidemiology 2003; 14: 287-9.

18 Richardson MT, Leon AS, Jacobs DR Jr, Ainsworth BE, Serfass R. Ability of the Caltrac accelerometer to assess daily physical activity levels. Journal of Cardiopulmonary Rehabilitation 1995; 15: 107-13.

19 Westwood M, Gibson JM, Davies AJ, Young RJ, White A. The phosphorylation pattern of insulin-like growth factor binding protein-1 in normal plasma is different from that in amniotic fluid and changes during pregnancy. Journal of Clinical Endocrinology and Metabolism 1994; 79: 1735-41.

20 Yates AP, Laing I. Age-related increase in haemoglobin A1c and fasting plasma glucose is accompanied by a decrease in beta cell function without change in insulin sensitivity: evidence from a cross-sectional study of hospital personnel. Diabetic Medicine 2002; 19: 254-8.

21 Matthews DR, Hosker JP, Rudenski AS, Naylor BA, Treacher DF, Turner RC. Homeostasis model assessment: insulin resistance and beta-cell function from fasting plasma glucose and insulin concentrations in man. Diabetologia 1985; 28: 412-9.

22 Ferrannini E, Mari A. How to measure insulin sensitivity. Journal of Hypertension 1998; 16: 895-906.

23 Underwood LE, Clemmons DR, Maes M, D'Ercole AJ, Ketelslegers JM. Regulation of somatomedin-C/insulin-like growth factor I by nutrients. Hormone Research 1986; 24: 166-76.

24 Clemmons DR, Klibanski A, Underwood LE, McArthur JW, Ridgway EC, Beitins IZ, et al. Reduction of plasma immunoreactive somatomedin-C during fasting in humans. Journal of Clinical Endocrinology and Metabolism 1981; 53 : 1247-50.

25 Kirschner BS, Sutton MM. Somatomedin-C levels in growth impaired children and adolescents with chronic inflammatory bowel disease. Gastroenterology 1986; 91: 830-6.

26 Kaklamani VG, Linos A, Kaklamani E, Markaki I, Koumantaki Y, Mantzoros CS. Dietary fat and carbohydrates are independently associated with circulating insulin-like growth factor 1 and insulin-like growth factor-binding protein 3 concentrations in healthy adults. Journal of Clinical Oncology 1999; 17: 3291-8.

27 Ferraris RP, Cao QX, Prabhakaram S. Chronic but not acute energy restriction increases intestinal nutrient transport in mice. Journal of Nutrition 2001; 31: 779-86.

28 Morgan EH, Oates PS. Mechanisms and regulation of intestinal iron absorption. Blood Cells, Molecules \& Disease 2002; 29: 384-99.

29 Gal-Garber O, Mabjeesh SJ, Sklan D, Uni Z. Partial sequence and expression of the gene for and activity of the sodium transporter in the small intestine of fed, starved and re-fed chickens. Journal of Nutrition 2000; 130: 2174-9.

30 O'Brien DP, Nelson LA, Huang FS, Warner BW. Intestinal adaptation: structure, function and regulation. Seminars in Paediatric Surgery 2001; 10: 56-64.

31 Lee PD, Giudice LC, Conover CA, Powell DR. Insulin-like growth factor binding protein-1: recent findings and new directions. Proceedings of the Society for Experimental Biology and Medicine 1997; 216: 319-57.

32 Cruickshank JK, Cooper J, Burnett M, Macduff J, Drubra U. Ethnic differences in fasting plasma C-peptide and insulin in relation to glucose tolerance and blood pressure. Lancet 1991; 338: 842-7.

33 McKeigue PM, Shah B, Marmot MG. Relation of central obesity and insulin resistance with high diabetes prevalence and cardiovascular risk in South Asians. Lancet 1991; 337: $382-6$.

34 Bang P, Brandt J, Degerblad M, Enberg G, Kaijser L, Thoren $\mathrm{M}$, et al. Exercise induced changes in insulin-like growth factors and their low molecular weight binding protein in healthy subjects and patients with growth hormone deficiency. European Journal of Clinical Investigation 1990; 20: 285-92.

35 Allen NE, Appleby PN, Kass R, Rinaldi S, Davey GK, Key TJ. Life style determinants of serum insulin-like growth factor-I, $\mathrm{C}$-peptide and hormone binding protein levels in British women. Cancer Causes \& Control 2003; 14: 65-74.

36 Hopkins NJ, Jakeman PM, Hughes SC, Holly JM. Changes in circulating insulin-like growth factor-binding protein-1 during prolonged exercise: effect of carbohydrate feeding. Journal of Clinical Endocrinology and Metabolism 1994; 79: 1887-90.

37 Cohen LA, Choi KW, Wang CX. Influence of dietary fat, calorie restriction and voluntary exercise on $\mathrm{N}$-nitrosomethylurea-induced tumorigenesis in rats. Cancer Research 1988; 48: 4276-83.

38 Hursting SD, Perkins SN, Phang JM. Calorie restriction delays spontaneous tumorigenesis in p53-knockout transgenic mice. Proceedings of the National Academy of Sciences of the USA 1994; 91: 7036-40.

39 Mukherjee P, Sotnikov AV, Mangian HJ, Zhou JR, Visek WJ, Clinton SK. Energy intake and prostate tumor growth, angiogenesis and vascular endothelial growth factor expression. Journal of the National Cancer Institute 1999; 91: $512-23$.

40 Dunn SE, Kari FW, French J, Leininger JR, Travlos J, Wilson R, et al. Dietary restriction reduces insulin-like growth factor-I levels, which modulates apoptosis, cell proliferation, and tumor progression in p53-deficient mice. Cancer Research 1997; 57: 4667-72. 